\title{
Understanding the Nexus of Climate Change and Migration: A Case of Dhye Peoples from Upper Mustang, Nepal
}

\section{Pragya Sherchan}

School of Environmental Science and Management (SchEMS), Pokhara University, Mid-Baneshwor, Kathmandu, Nepal. Email: sherchanpragya001@ gmail.com

How to cite this paper: Sherchan, $\mathrm{P}$. (2019). Understanding the Nexus of Climate Change and Migration: A Case of Dhye Peoples from Upper Mustang, Nepal. Grassroots Journal of Natural Resources, 2(1-2): 1-19. Doi:

https://doi.org/10.33002/nr2581.6853.02121

Received: 03 May 2019

Reviewed: 07 May 2019

Provisionally Accepted: 10 May 2019

Revised: 15 May 2019

Finally Accepted: 20 May 2019

Published: 20 June 2019

Copyright $\odot 2019$ by author(s) and

The Grassroots Institute.

This work is licensed under the Creative Commons Attribution International License (CC BY 4.0). http://creativecommons.org/licenses/by/4.0/
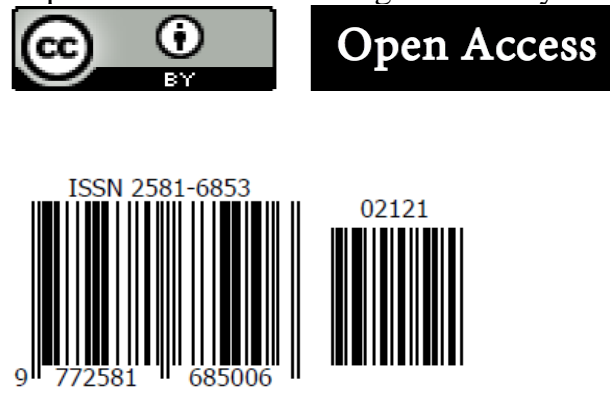

\begin{abstract}
People of Dhye village are recognized as the Nepal's first climate refugees. Historical records show that mass migration of people from Dhye village has occurred for three times, with latest one attributed to the climate change. This article aims to explore and understand the underlying causes of the Dhye people's migration, and to analyze the land suitability for their relocation. The article discusses that people of Dhye have migrated mainly to look for livelihood options, water availability and land for cultivation. As of now, more than two dozen water ponds have dried completely, and the only community reservoir serves as main source of irrigation water. This led to a decrease in cultivated area by onefourth within last 40 years. The livestock farming has also been decreasing year by year with only one yak herder left in the entire Dhye village. The temperature trend is positive, whereas precipitation trend is negative. The land suitability analysis done by using Multi-Criteria Decision Analysis (MCDA) shows that Thangchung Chawale village is more suitable location than Dhye village in terms of cultivation area, water availability, and distance to health-post and transportation facilities.
\end{abstract}

\section{Keywords}

Climate change; Land suitability; Dhye; Climate refugee 
Doi: https://doi.org/10.33002/nr2581.6853.02121

\section{Introduction}

The high-altitude cold deserts of greater Himalayan region or Trans-Himalayan region are among the most vulnerable ecosystems to climatic changes (Christensen and Heilmann, 2009; Sharma and Tshering, 2009). According to IPCC (2007), the adverse effects of changing weather patterns and climate have extended beyond crop cultivation and, thus, influence livelihoods of people. Mustang is an ancient isolated kingdom located in the Trans-Himalaya region of north-western Nepal with very low population density and arid cold climate. The region hosts a range of human societies whose main source of livelihood is livestock farming and agriculture. Like other high mountains, Mustang also represents fragile ecosystem, and inhabitant communities try to balance their livelihood with available resources. Mustang is divided into two regions: Upper Mustang and Lower Mustang. Lo-pa (Upper Mustang) falls under rain-shadow zone of Nepal. Upper Mustang is also known for its severe winter and is one of the coldest regions of Nepal, as the temperature drops down to $-20^{\circ}$ to $-30^{\circ}$ Celsius in winter. In summer, the temperature remains between $0^{\circ} \mathrm{C}$ to $10^{\circ} \mathrm{C}$ (Dhungel, 2002). Life and livelihood in many mountain settlements in Nepal are under stress from desertification, drought and water scarcity (Shrestha, 2016).

Human migration is not a new phenomenon occurring due mainly to the poverty and environmental shocks. There are many pulling and pushing factors for human displacement. The migration decision is taken by families and households rather than the individuals alone, to maximize expected earnings and reduce the risk of consumption failure by diversifying income sources across sectors or agro-zones (Jha et al., 2018). Scheffran, Marmer and Snow (2012) expressed that the human migration is not only a response to poverty and social deprivation, but it is also an adaptive response to changing climate. The communities from some of the Trans-Himalayan settlements such as Dhye, Samjong and Yara have expressed their sufferings owing to water scarcity, particularly during the dry season. These three communities are situated in the upper Mustang area of Mustang district. Reportedly, communities from Dhye (4000 masl) are ready to move to Thangchung Chawale (3500 masl), located north-west at the bank of Dhye Khola tributary that later joins the Kali Gandaki river. They had migrated from Nakkali-Damodarkunda to Zhong, and to Dhye (Devkota, 2013).

\section{Study Area}

Mustang district is one of the 77 districts of Nepal. Mustang district lies on Dhaulagiri Zone of Western Development Region of Nepal, which is divided into two regions: lower Mustang and upper Mustang. The headquarter is Jomsom, which covers an area of $3,573 \mathrm{~km}^{2}$ and has population of 13,452 (2011). Dhye village is from Lo-pa (Upper Mustang), lies in Lo-Ghekar Damodarkunda Rural Municipality of ward no. 5. This village is located at $29^{\circ} 2^{\prime} 30^{\prime \prime}$ North and $083^{\circ} 5^{\prime}$ '92" East and lies at 3860 masl (Figure 1). It consists of 26 households with a population of 163 people. Due to low access to water, they grow wheat, naked barley and maize that need little water. They practice animal husbandry, mostly mountain goat, sheep, and high-altitude cattle like yak. The yak has thick fur and can withstand severe cold and drought because it can thrive on thorny plants (Shrestha, 2016). The climate varies from alpine to tundra type where temperature ranges from $10^{\circ} \mathrm{C}$ to $26^{\circ} \mathrm{C}$, and annual mean precipitation ranges from $3.25 \mathrm{ml}$ to $13 \mathrm{ml}$ (LAPA, 2016). 


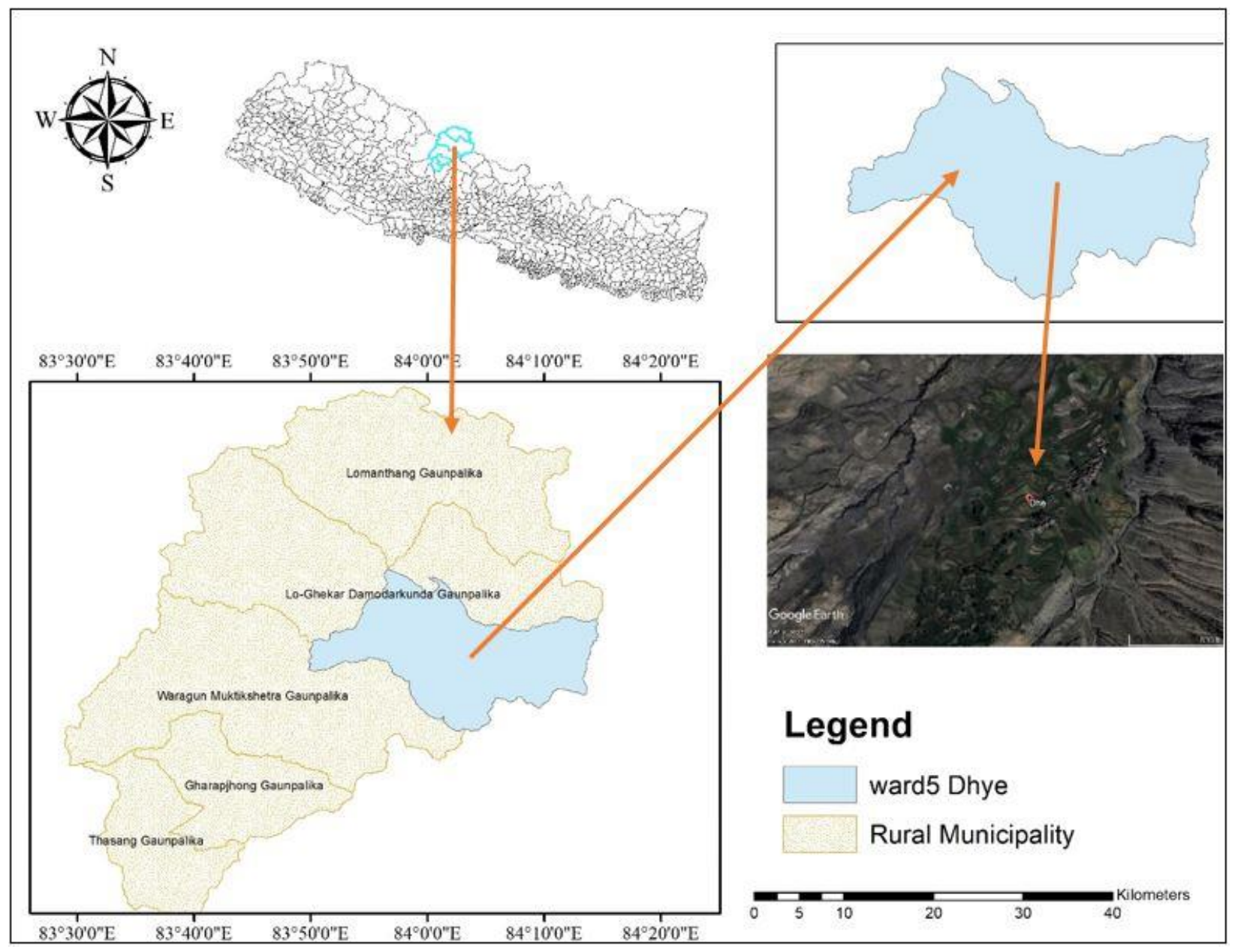

Figure 1: Map of Study Area (Source: Nepal Department of Survey, 2017)

\section{Materials and Methods}

The present article is based on the study relying on both primary and secondary data sources. Field data was collected in October 2018 covering both qualitative and quantitative techniques.

The household survey was conducted to gather basic information on socio-economic status, possible causes of migrations in different places, people's perception on climate change and natural hazard ranking. Only 23 household were present at the site, so the respondents were purposively selected. The semi-structured questionnaires were used to collect quality information. Similarly, KII (Key Informant Interview) was used to find in-depth information from 5 key persons: representatives of Lo-Ghekar Damodarkunda Rural Municipality, Annapurna Conservation Area, Mukhiya, chairman of club and chairman of resettlement committee. Field observation of all the migratory sites was also done for the validation of the household survey's information. The secondary data were collected from Department of Hydrology and Meteorology (DHM), District Agriculture Development Office (DADO) and Central Bureau of Statistics. The MS Excel, Mann Kendall Correlation (SPSS), GPS and Google Earth Pro were used to analyze data. The Digital Elevation Model (DEM) of $30 \times 30$ resolution was extracted from SRTM (Shuttle Radar Topography Mission) and the study area layer was digitized from Geo-Eye Satellite image from 


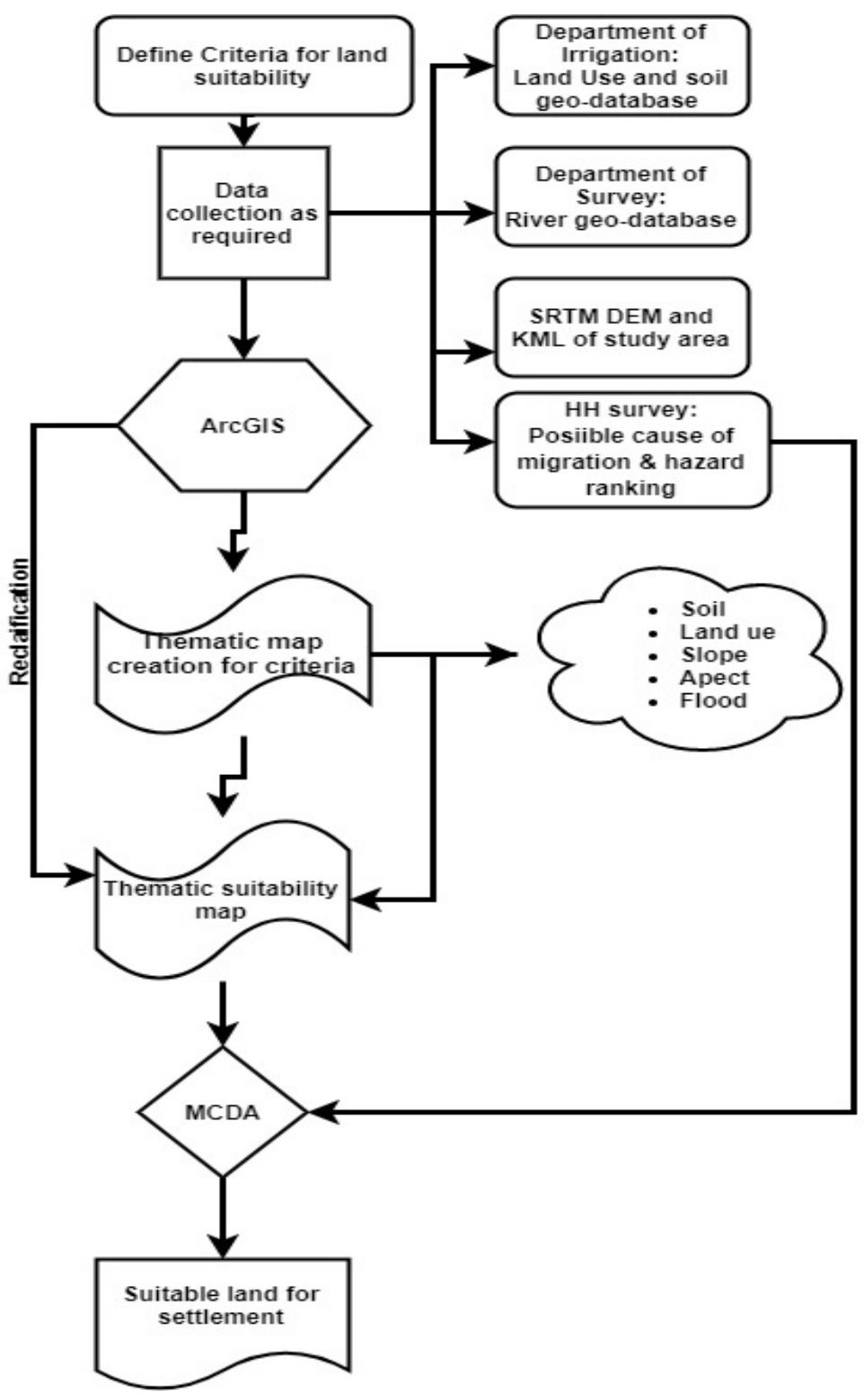

Figure 2: Procedure for land suitability analysis
Google Earth Pro. The land use and soil data were collected from Department of Irrigation. River data and transportations data were collected from Survey Department of Nepal. The land suitability criteria such as agriculture, soil erosion, flood and livelihood were extracted from the possible causes of migration in different migratory sites and from the natural hazard ranking. For the hazard ranking, at an initial step, all the hazards that occurred in Dhye and Thangchung Chawale were listed by involving the villagers. In the second step, each of the listed hazards was compared in pairs and the hazards that had more impact on the villagers were noted. Finally, all the noted hazards were counted, and highest number scored hazard was ranked as $1^{\text {st }}$ and then $2^{\text {nd }}, 3^{\text {rd }}$ and so on. Higher the number scored higher is the rank.

All the methods were conducted for comparison between two sites - Dhye and Thangchung Chawale designated for resettlement. Then the criteria were divided into sub-criteria as required and respective data were collected from different data sources as shown in Figure 2. After acquiring data, an analysis was done using ArcGIS and thematic maps produced for criteria and sub-criteria. The

thematic maps were reclassified into suitable, moderately suitable and unsuitable to prepare thematic land suitability map. Thereafter, a comparison between all the criteria and sub-criteria was done in pairs using MCDA and score was given from -1 to +1 . The high scoring site was concluded as more suitable land for resettlement.

\section{Results}

\section{Demography}

There are 26 households with a population size of 163 people (88 male and 75 female) in Dhye village (study area). All the villagers were of same clan "Gurung" and follow Buddhism religion. The education status of the male population was higher than that of the females and most of the 
villagers have obtained primary education. Their main occupation was agriculture and livestock farming. They cultivate barley, naked barley, potato, radish, spinach, cabbage, cauliflower, mustard, apple, peach, apricot, etc.

\section{Migration Pattern}

In the history, the people of Dhye have migrated from Ghayu/ Ghayul at about 5000 masl. Ghayu is the local name. "Gha" means mountain, and "yul" means village; a village at the base of mountain. Ghayul is located at the base of Bhrikuti mountain and is also known as "Nakkali Damodarkunda". Nowadays, it is also known as "Ghayu kharka", a name given by Sherpa guide as it is a trekking trail for Damodarkunda (religious Lake) and for Nilgiri summit. Even today, one can see the remnants of a settlement, cultivated land and irrigation cannels at Ghayu.

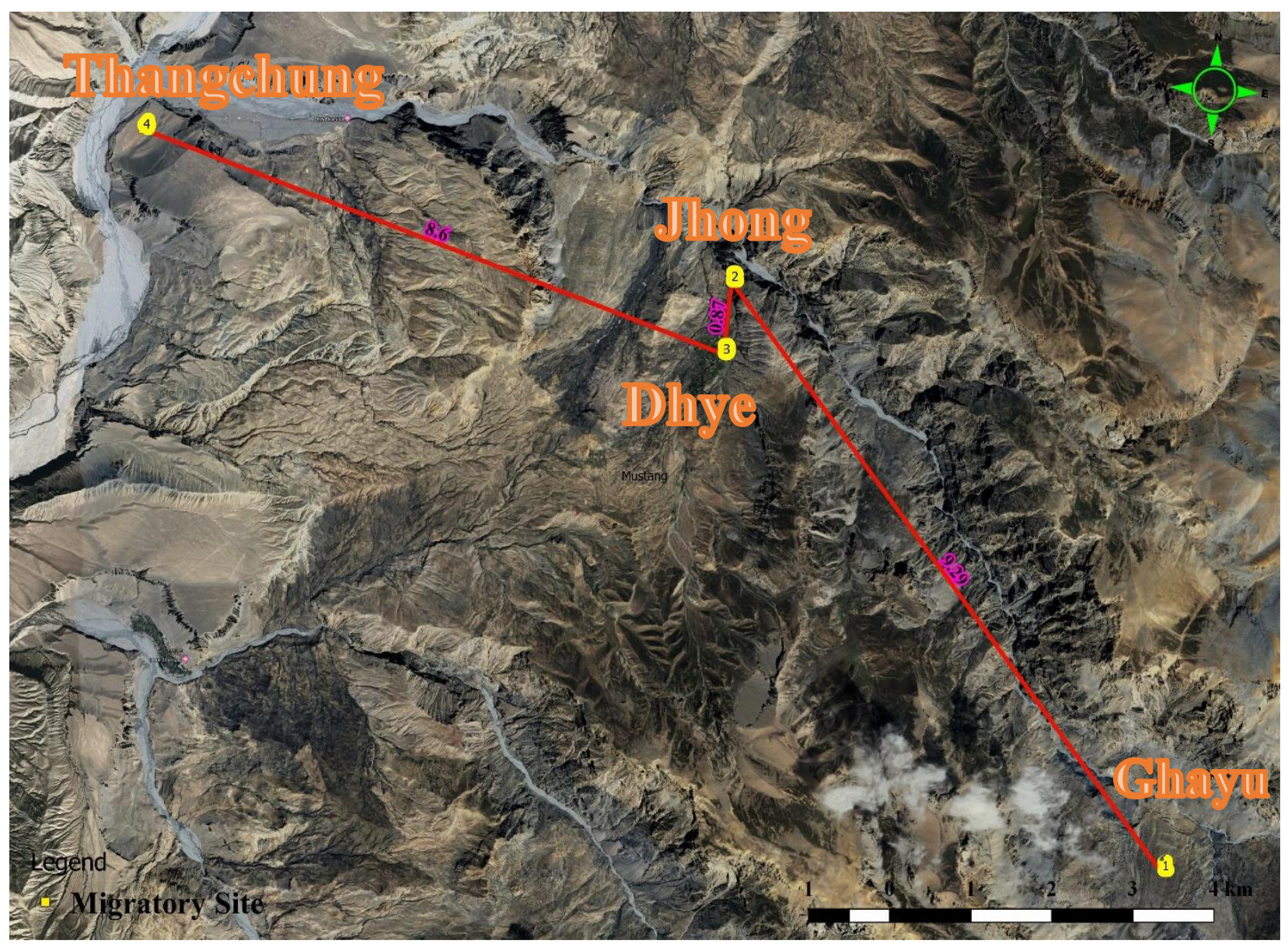

Figure 3: Different migratory sites of Dhye people (Source: USGS, Geo-Eye Satellite image)

From Ghayu they had migrated to Jhong, located at about 3800 masl. Jhong is also the local name that means "cave". It is at a walking distance of about $0.87 \mathrm{~km}$ from Dhye village downhill. From Jhong, they had migrated to Dhye village, their current place of living located at about 4000 masl (refer Figure 3). It is a beautiful place. Dhye seems to be the only place where human settlement was possible among these three villages.

Causes of migration of these people are highlighted in the table 1. 
Doi: https://doi.org/10.33002/nr2581.6853.02121

Table 1: Possible causes for migration in different places and their livelihood options

\begin{tabular}{|l|l|l|l|l|l|}
\hline S.N. & $\begin{array}{c}\text { Place name } \\
\text { (migrated } \\
\text { from) }\end{array}$ & $\begin{array}{c}\text { Approximate } \\
\text { time (years } \\
\text { before) }\end{array}$ & $\begin{array}{c}\text { Distance } \\
\text { from } \\
\text { Dhye }\end{array}$ & $\begin{array}{l}\text { Livelihood } \\
\text { options }\end{array}$ & \multicolumn{1}{|c|}{$\begin{array}{c}\text { Reasons for migration } \\
\text { (from/to) }\end{array}$} \\
\cline { 1 - 5 } 1. & $\begin{array}{l}\text { Ghayu to } \\
\text { Jhong }\end{array}$ & $\begin{array}{l}\text { Approximately } \\
500-1000 \\
\text { years back }\end{array}$ & $9.29 \mathrm{~km}$ & $\begin{array}{l}\text { Livestock } \\
\text { cultivation } \\
\text { and } \\
\text { hunting }\end{array}$ & $\begin{array}{l}\text { Soil erosion, weather, } \\
\text { deficient agricultural land, } \\
\text { no irrigation due to soil } \\
\text { erosion, avalanche and } \\
\text { safety }\end{array}$ \\
\cline { 1 - 2 } 2. & Jhong to Dhye & $0.87 \mathrm{~km}$ & $\begin{array}{l}\text { Livestock } \\
\text { and } \\
\text { cultivation }\end{array}$ & $\begin{array}{l}\text { Enough agricultural land, } \\
\text { water availability, enough } \\
\text { irrigation, and pasture land }\end{array}$ \\
\hline 3. & $\begin{array}{l}\text { Dhyey to } \\
\text { Thangchung } \\
\text { Chawale }\end{array}$ & $\begin{array}{l}350 \text { to } 400 \\
\text { years }\end{array}$ & $8.6 \mathrm{~km}$ & $\begin{array}{l}\text { Livestock } \\
\text { and } \\
\text { cultivation }\end{array}$ & $\begin{array}{l}\text { Decrease in agricultural } \\
\text { production due to drought, } \\
\text { deficiency of water, lack of } \\
\text { health facilities, inadequate } \\
\text { education }\end{array}$ \\
\hline
\end{tabular}

\section{Occupation}

The major occupation or source of livelihood of the people of Dhye village is agriculture, livestock, hotel and government jobs. There is now change in number of people having livestock, which is shown in the figure below:

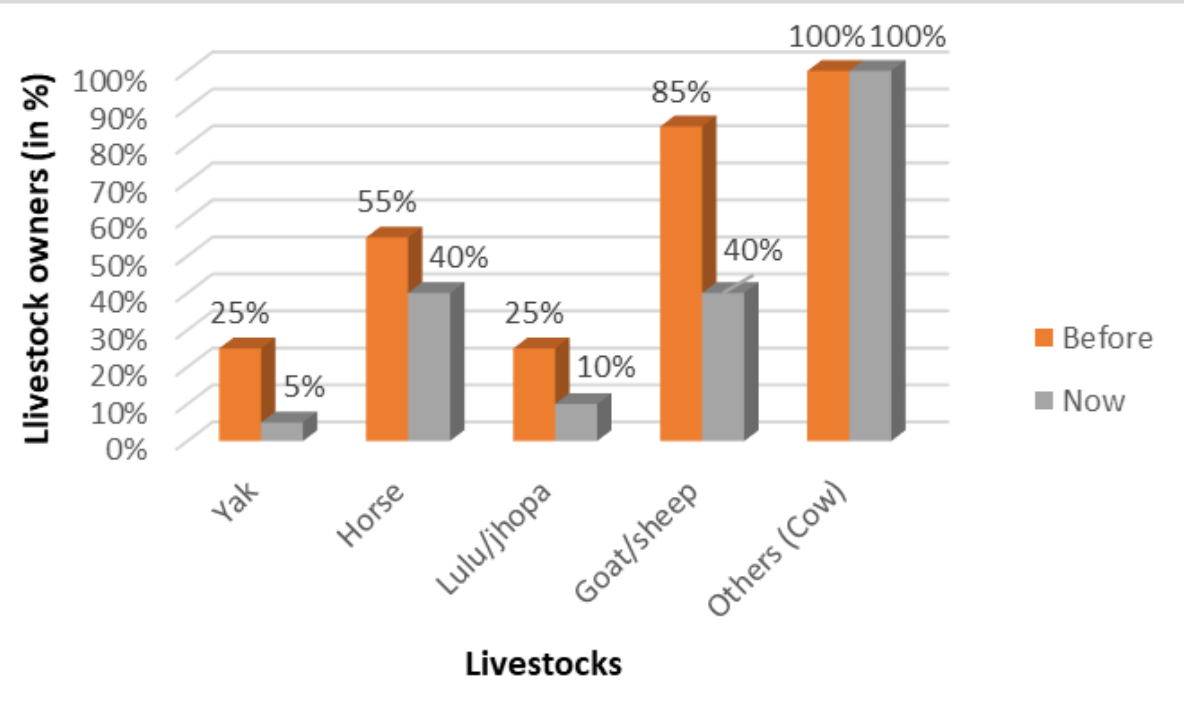

Figure 4: Change in number of people having livestock

$25 \%$ of the respondents were raising yak before, but yak raising decreased to $5 \%$, i.e. only one person is rearing yak in the whole village. Mr. Kunsang Rinzin Gurung is the last yak herder of the Dhye village. Similarly, there is decrease in all the livestock except cow, i.e. $100 \%$ respondents. 
The horse rearing has decreased from $55 \%$ to $40 \%$. Similarly, $25 \%$ to $10 \%$ and $85 \%$ to $40 \%$ decrease in lulu/jhopa ${ }^{1}$ and goat/sheep, respectively, due to the degrading grazing lands (Figure 4).

\section{Change in Climate}

The maximum number of respondents, i.e.18, said that there is change in temperature. The temperature has been increasing over past few decades. $100 \%$ respondents said that there is change in time, duration and intensity of rainfall and snow fall. There is change in amount, intensity and time of precipitation, which ultimately affected the agricultural practices and condition of pasture lands. Hailstorm does not occur in the study area. 11 respondents said that there was change in wind speed and time, whereas 5 respondents negated, and 4 respondents affirmed the same answer (Figure 5).

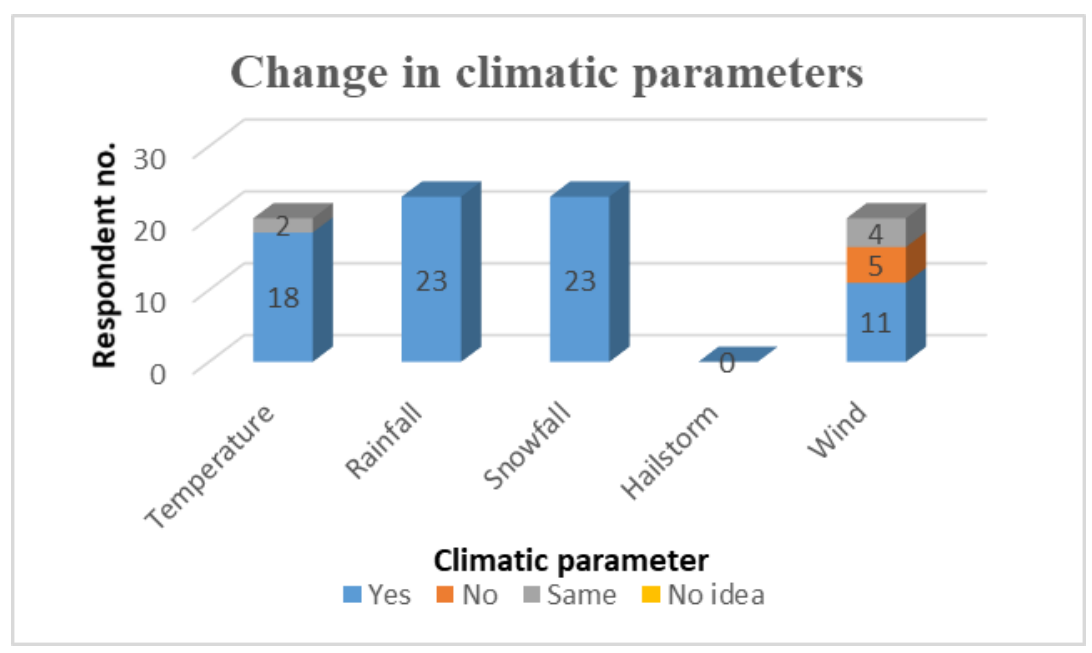

Figure 5: Change in climatic parameters

The water is the most affected sector (50\%) as a consequence of climatic variations. It is followed by agriculture, health and livelihood, forest, livestock and education sectors (Figure 6).

Figure 6: Different sectors affected due to change in climatic parameters

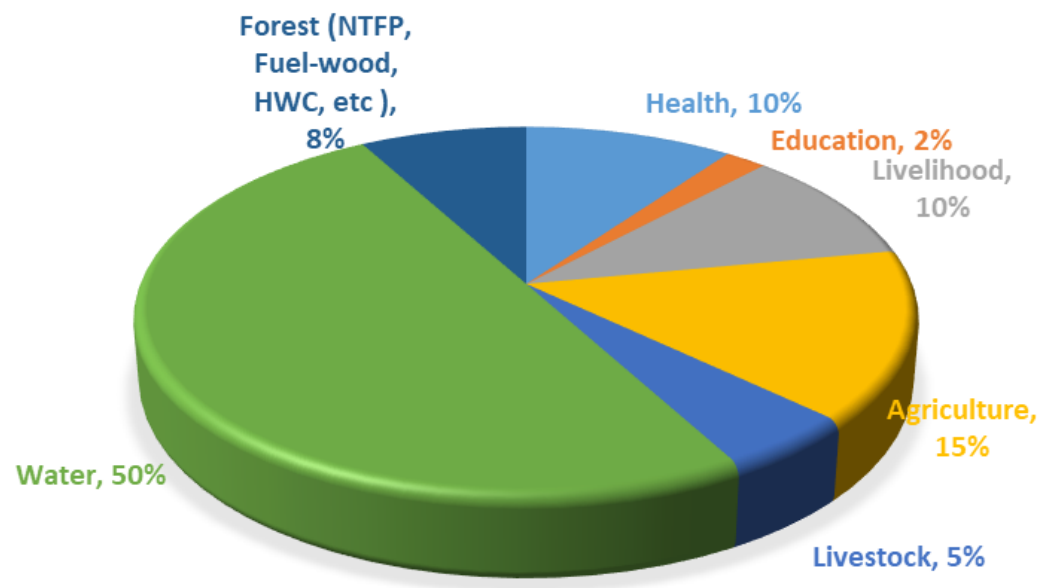

Narration in Table 2 highlights problems caused by climate change and some suggested options.

\footnotetext{
${ }^{1}$ Cross breed of yak and cow
} 
Doi: https://doi.org/10.33002/nr2581.6853.02121

Table 2: Major problems and their adaptation options for different sectors

\begin{tabular}{|c|c|c|c|}
\hline S.N. & Different sectors & Major problems & Adapting options \\
\hline 1. & Health & $\begin{array}{l}\text { No health facilities, lack of } \\
\text { awareness about health and } \\
\text { sanitation }\end{array}$ & $\begin{array}{l}\text { Amchi practices }{ }^{2} \text {, salt tea for } \\
\text { water contain in body }\end{array}$ \\
\hline 2. & Education & $\begin{array}{l}\text { School is closed due to lack of } \\
\text { students and teacher }\end{array}$ & $\begin{array}{l}\text { Children are sent to lower } \\
\text { regions (Jomsom, Tsarang), } \\
\text { Pokhara, Kathmandu, India for } \\
\text { education facility }\end{array}$ \\
\hline 3. & Livelihood & $\begin{array}{l}\text { Less cultivating practices, } \\
\text { insufficient water for irrigation } \\
\text { and drinking, not enough fuel } \\
\text { sources, insufficient pasture } \\
\text { lands, decrease in livestock } \\
\text { numbers, no transportation } \\
\text { facilities }\end{array}$ & $\begin{array}{l}\text { Solar lights and mill, water mill, } \\
\text { improved cooking stove, tap } \\
\text { water, new variety and hybrid } \\
\text { seed of crops and vegetables, } \\
\text { migration }\end{array}$ \\
\hline 4. & Agriculture & $\begin{array}{l}\text { Insufficient water for irrigation, } \\
\text { drought }\end{array}$ & $\begin{array}{l}\text { Use of new species, use of } \\
\text { improved variety of crops, } \\
\text { rotational irrigation, greenhouse } \\
\text { and stopped cultivating land }\end{array}$ \\
\hline 5 . & Livestock & Insufficient pasture land & $\begin{array}{l}\text { Stopped raising livestock, } \\
\text { practicing cultivating green } \\
\text { vegetables }\end{array}$ \\
\hline 6. & Water & $\begin{array}{l}\text { Water sources (springs and } \\
\text { ponds) are drying up }\end{array}$ & $\begin{array}{l}\text { Artificial pond reservoir, } \\
\text { rotational irrigation, plantation } \\
\text { of bhotepipal (Populus ciliate) } \\
\text { and bains (Salix folia) }\end{array}$ \\
\hline 7. & $\begin{array}{l}\text { Forest }\left(\mathrm{NTFP}^{3},\right. \\
\text { fuelwood, } \\
\left.\mathrm{HWC}^{4} \text {, etc. }\right)\end{array}$ & $\begin{array}{l}\text { not enough forest, very far from } \\
\text { settlement, not enough grazing } \\
\text { land, jimbu (Allium hypsistum) } \\
\text { (NTFP) has been extinct }\end{array}$ & $\begin{array}{l}\text { Improved cooking stove, use of } \\
\text { cow, goat and yak dung as a } \\
\text { fuel, use of gas stove, plantation } \\
\text { of bhotepipal (Populus ciliate) } \\
\text { and bains (Salix folia) }\end{array}$ \\
\hline
\end{tabular}

\footnotetext{
${ }^{2}$ In general, amchi medical practice is also identified by the name sowa rigpa, which means "science of healing" in classical Tibetan as well as in regional Himalayan and Central Asian languages and dialects. The word amchi means "doctor". This system of medicine is a spiritual practice, a science, and an art that dates back thousands of years. Aspects of this medicine system were transmitted from India to Tibet between the 7th and 12th centuries, during the first and second dissemination of Buddhism. This system combines the profound work of Sangye Menla, the Medicine Buddha, with indigenous Tibetan traditions such as Bön, and was shaped into sowa rigpa as it is known today (Source: http://www.drokpa.org/amchi.html).

${ }^{3}$ Non-Timber Forest Products

${ }^{4}$ Human Wildlife Conflict
} 


\section{Types of Crops Cultivated in Dhye-Chawale}

The major crops are wheat (Triticum aestivum), barley (Hordeum vulgare), pea (Pisum sativum), buckwheat (Fagopyrum esculentum), mustard (Brassica compestris), potato (Solanum tuberosum), spinach (Spinacia oleracea), cauliflower (Brassica oleracea var. botrytis), cabbage (Brassica oleracea var. capitata), apple (Malus domestica), etc. Fruits cultivation was not practiced earlier. However, of late, they have started cultivating fruits, mostly apple. In the year 2011, they formed a cooperative organization called "Dhye Thangjung Agricultural Cooperative Organization" with a mandate to develop fruits cultivation for sustenance. They have used 132 hectares of government land at Chawale and started plantation of 8000 apple plants, 200 walnut (Juglans regia), 200 apricot (Prunus armeniaca) and 200 peach (Prunus persica) plants. It has been 8 years now, and they have started harvesting apples, apricot and peach to earn revenue. Walnut has not started fruiting yet.

According to the District Agricultural Development Office, apple can be cultivated on elevation ranging from 2000 to 3000 masl. However, now apples are also being grown above this altitude range. Chawale is at about 3500 masl and these people are cultivating and harvesting apples since 2015. The people of Dhye can only cultivate crops once a year, which is not enough for them to survive round the year. According to the villagers, they are cultivating cereals every year; however, within the last 30 to 40 years almost $75 \%$ of the land is left uncultivated due to water scarcity for irrigation. The Upper Mustang people had started cultivating green vegetables after the Care Nepal trained them 30 years ago. It is said that the Lo people used to have meats and cereals they grew. But now it has changed, and they are cultivating green vegetables.

\section{Status of water sources}

In the study area, five water sources were spotted: Napromo, Puchhumi, Phungmukere and Hyulu for irrigation purpose and Nhamo for drinking purpose. Figure 7 shows that most of the respondents said that the condition of water sources has been decreasing everywhere except Nhamo (Figure 7). These water sources used to be more than 2 dozen private and community ponds. Nowadays, due to the decreased water volume, the villagers are collecting water in only one artificial pond for irrigation (red area). It is a matter of concern that these water sources completely dry up during the winter season. There are two water taps constructed by Care Nepal in the village; they run for just six months. During rest six months (from October to March) they run completely dry. Similarly, the artificial ponds also get dried up for three months (from November to January).

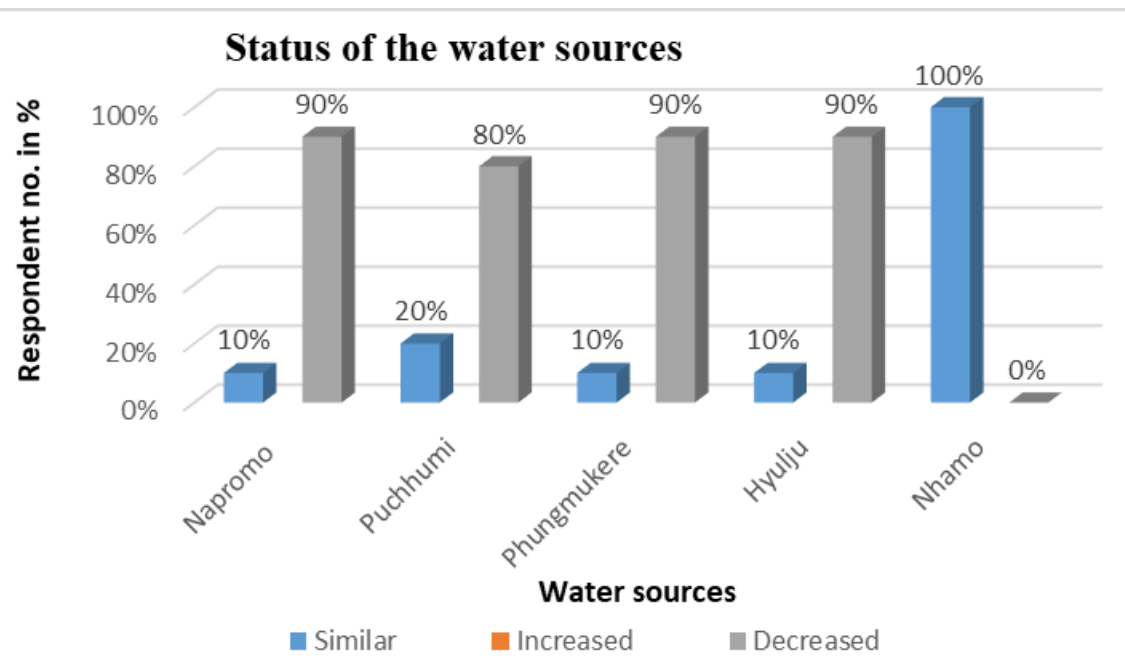

Figure 7: Status of water sources of Dhye village 


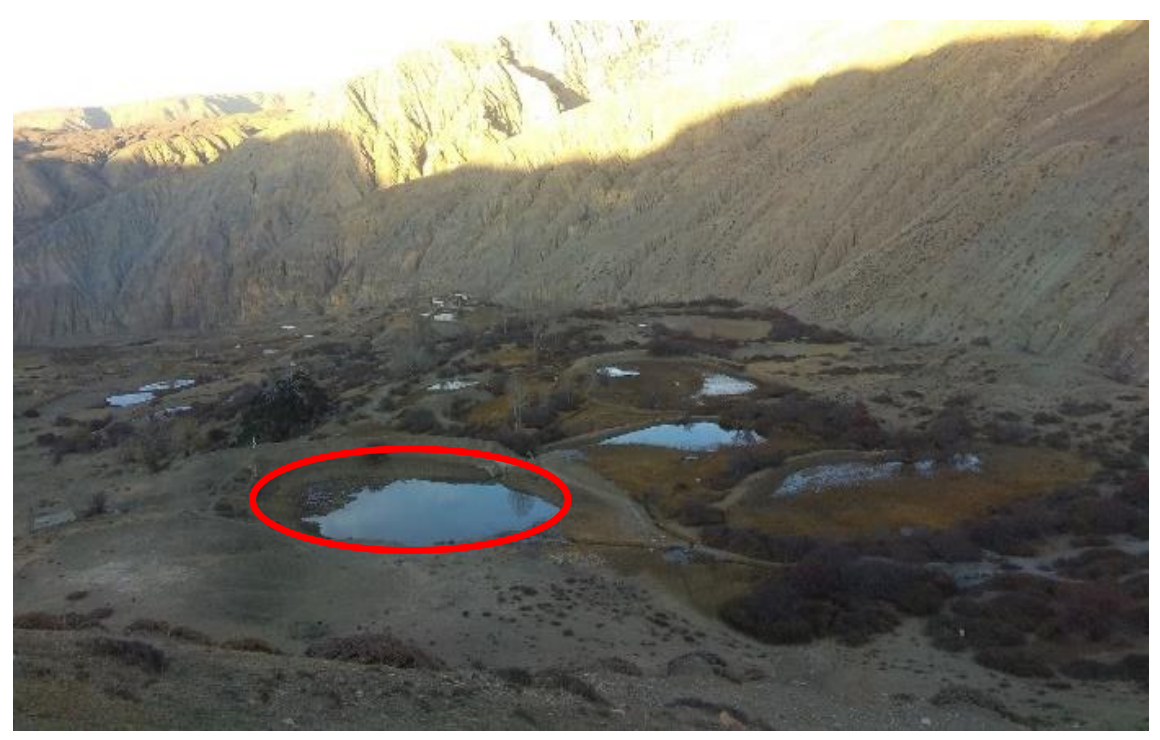

Picture 1: Only remaining artificial community pond

It was learnt that the condition of the pasture lands used to be very good earlier. However, with the passage of time, due to erratic rainfall, snowfall, and seasonal changes in terms of intensity and duration, the pasture lands have been degrading by years. The following table represents the pasture land conditions based on the responses from the respondents.

Table 3: Status of the pasture lands

\begin{tabular}{|c|c|c|c|c|}
\hline \multirow{2}{*}{ S.N. } & \multirow{2}{*}{ Name of pasture land } & \multicolumn{2}{|c|}{ Pasture land condition } & Remarks \\
\hline & & Before & Now & \multirow{12}{*}{$\begin{array}{l}\text { Pasture lands are } \\
\text { degrading due to } \\
\text { the decrease in } \\
\text { rainfall and changes } \\
\text { in snowfall pattern } \\
\text { and time } \\
\text { (unseasonal) }\end{array}$} \\
\hline 1. & Ghayu & Very good & Good & \\
\hline 2. & Ghoma & Very good & Very bad & \\
\hline 3. & Kya & Very good & Good & \\
\hline 4. & Jhotang & Very good & Good & \\
\hline 5. & Nihmalokchu & Very good & Good & \\
\hline 6. & Tsathang & Very good & Good & \\
\hline 7. & Nakti & Excellent & Very good & \\
\hline 8. & Chawale & Excellent & Very good & \\
\hline 9. & Ghomar & Very good & Good & \\
\hline 10. & Kripchyu & Very good & Good & \\
\hline 11. & Thotang & Excellent & Good & \\
\hline
\end{tabular}


Doi: https://doi.org/10.33002/nr2581.6853.02121

\section{Mann Kendall Correlation Coefficient (Tau-b test) for Climate Data Analysis}

Data in Table 4 shows that there is significant relationship between maximum temperature (Tmax) and mean temperature with year 1988-2017. As the significant $\mathrm{p}$ values for Tmax and mean temperature (0.02 and 0.03 ) are less than 0.05 , the correlation is significant at the 0.05 level. Along with that, there is positive correlation between them, as the correlation coefficient is same i.e. 0.29 for both. There is no significant relationship between minimum temperature (Tmin) and year 19882017. As the significant $\mathrm{p}$ value for Tmin 0.36 is greater than 0.05 , there is positive correlation between them, as the correlation coefficient is 0.12 .

Table 4: Mann Kendall Correlation between Year (1988-2017) and Temperature, Jomsom

\begin{tabular}{lll}
\hline Variables & Correlation coefficient $(r)$ value & Significance $(p)$ value \\
\hline Tmax and year & 0.29 & 0.02 \\
Tmin and year & 0.12 & 0.36 \\
Mean Temp & 0.29 & 0.03 \\
\hline
\end{tabular}

Table 5: Mann Kendall Correlation between Year (1988-2017) and Precipitation

\begin{tabular}{lll}
\hline Variables & Correlation coefficient $(r)$ value & Significance $(p)$ value \\
\hline $\begin{array}{l}\text { Mean ppt and year (Jomsom, } \\
\text { year (1988-2017) }\end{array}$ & 0.337 & 0.009 \\
$\begin{array}{l}\text { Mean ppt and year (Ghami, } \\
\text { year (1983-2012) }\end{array}$ & -0.190 & 0.155 \\
\hline
\end{tabular}

Table 5 shows that here is significant relationship between mean precipitation and year (1988-2017) for Jomsom. As the significant $p$ value for mean precipitation is 0.009 , which is less than 0.01 . Hence, the correlation is significant at the 0.01 level. Along with that, there is positive correlation between them, as the correlation coefficient is 0.337 . There is no significant relationship between mean precipitation and year (19832012) for Ghami. As the significant $p$ value 0.155 is greater than 0.05 , there is negative correlation between them, as the correlation coefficient is -0.190 .

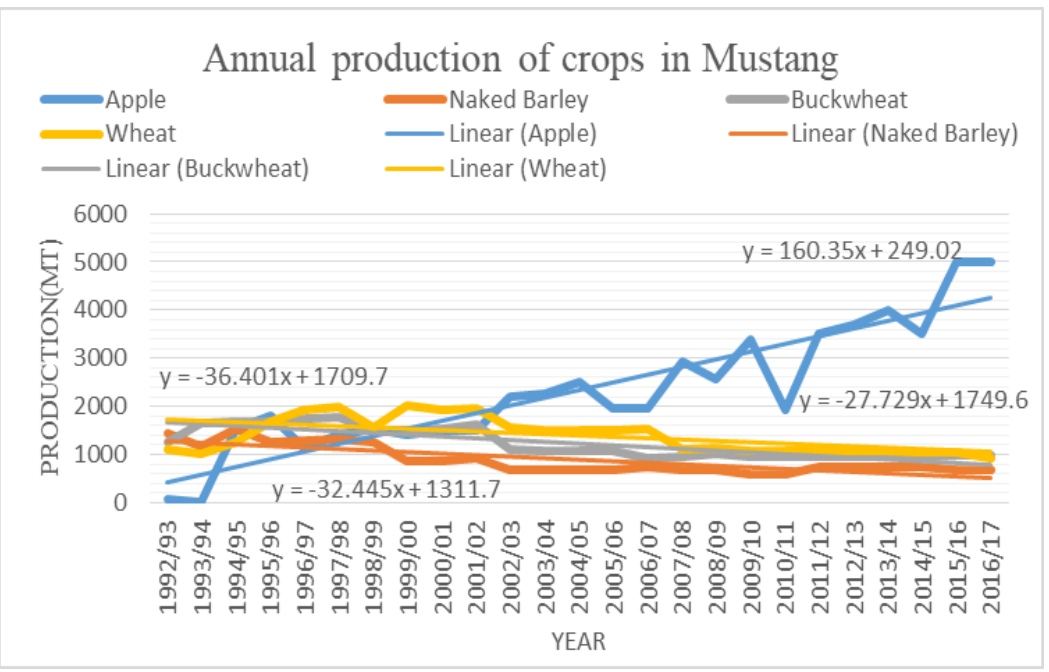

Figure 8: Crops production trend in Mustang

\section{Crops Production and Population Trend Analysis}

The Figure 8 depicts the production trend of all the crops such as naked barley, buckwheat and wheat. It is in decreasing trend. The production trend of apple is dramatically increased (160.35 mt/year). The drastic change is seen after year 1993/94. 
The population census is only available for five decades from 1971 to 2011 for study area and for Mustang district. The Figure 9 shows decreasing population trend for both Mustang district as well as for Surkhang. It seems that the present population of Mustang is half of the population number of 1971. Similarly, the population of Surkhang is less than $1 / 4^{\text {th }}$ population of 1971 .

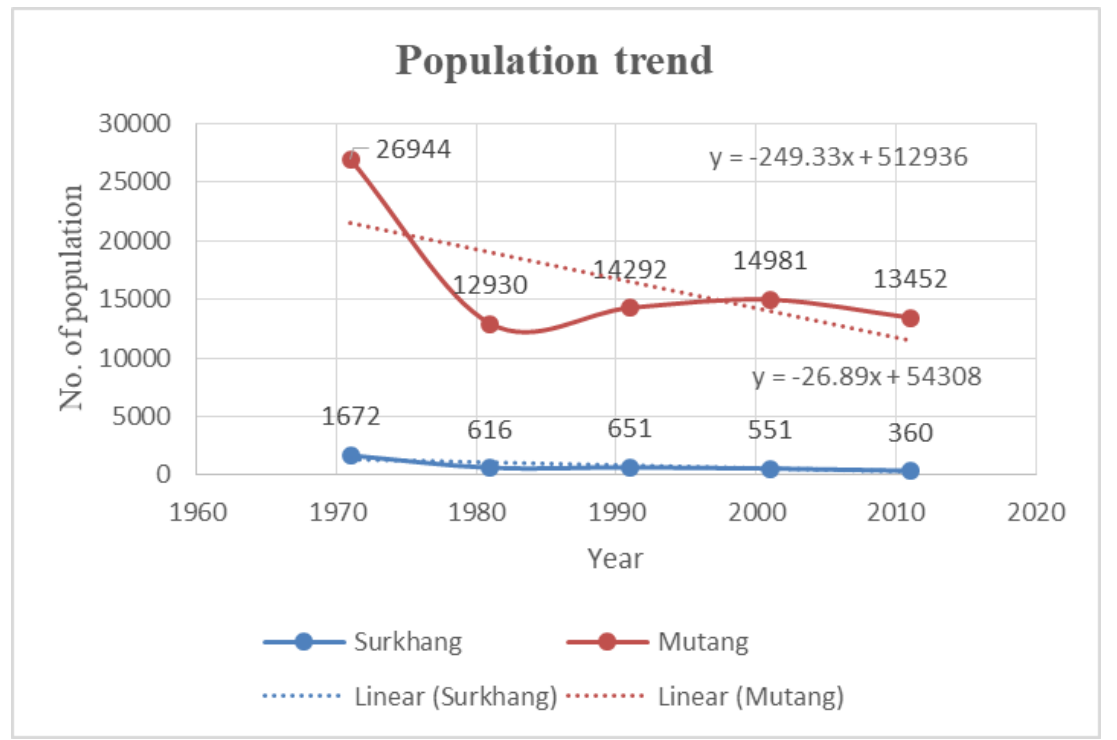

Figure 9: Population trend analysis

Land Suitability Analysis for Thangchung Chawale and Dhye

Soil suitability for Thangchung Chawale and Dhye

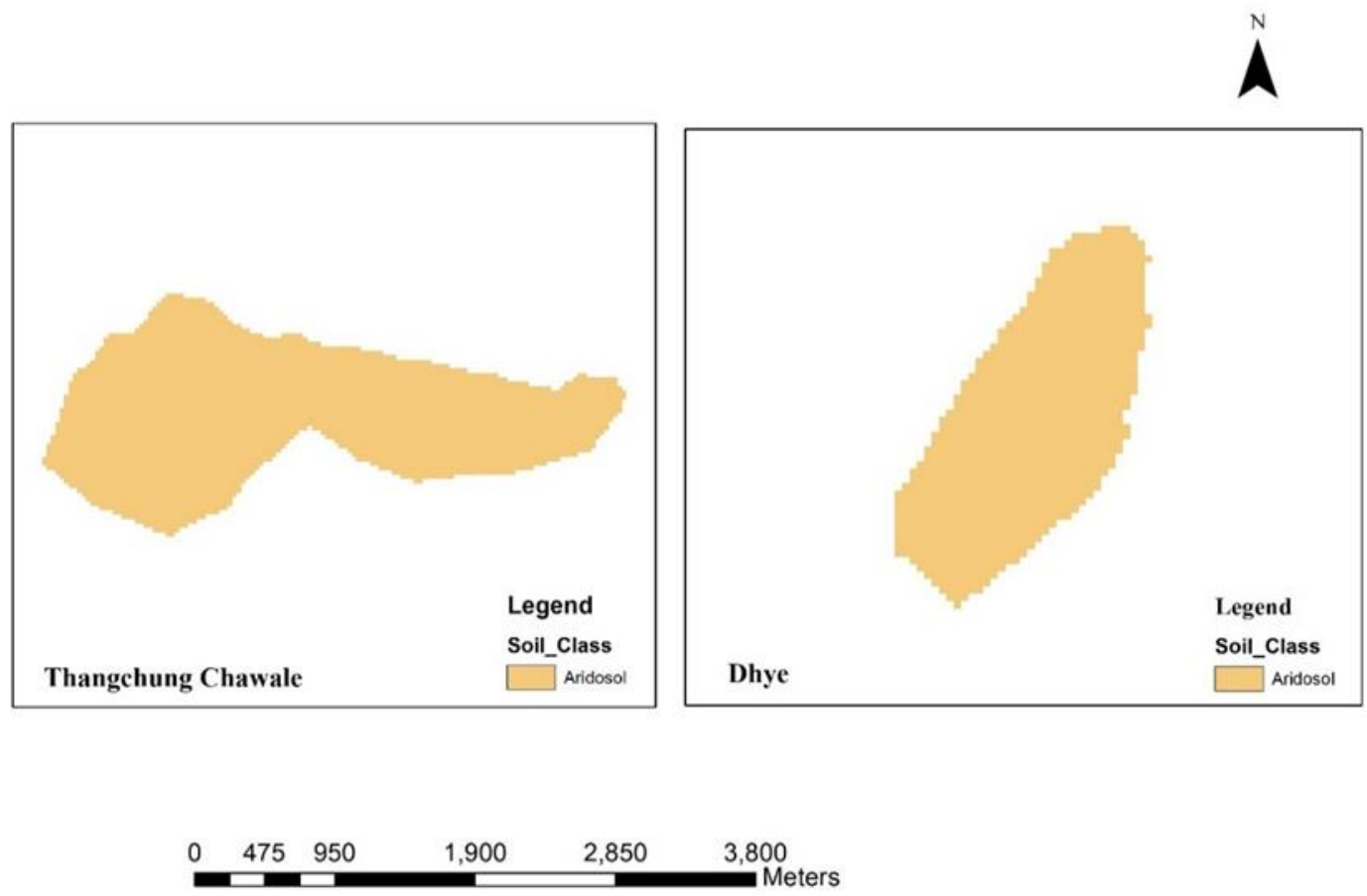

Figure 10: Land suitability maps for soil 
The Figure 10 exhibits that there is only one type of soil class for both the settlements i.e., Aridosol, which is a soil of arid climate and is common in the desert regions. They often have accumulations of lime $\left(\mathrm{CaCO}_{3}\right)$, sodium or salts. Water deficiency is the dominant characteristics of Aridosol. Productivity of Aridosol is generally low and there is potential for land degradation due to overgrazing by livestock (Ruben, Garcia and Frankentein, 2015). But if the irrigation is made available then they can be made productive through the use of fertilizers and proper management

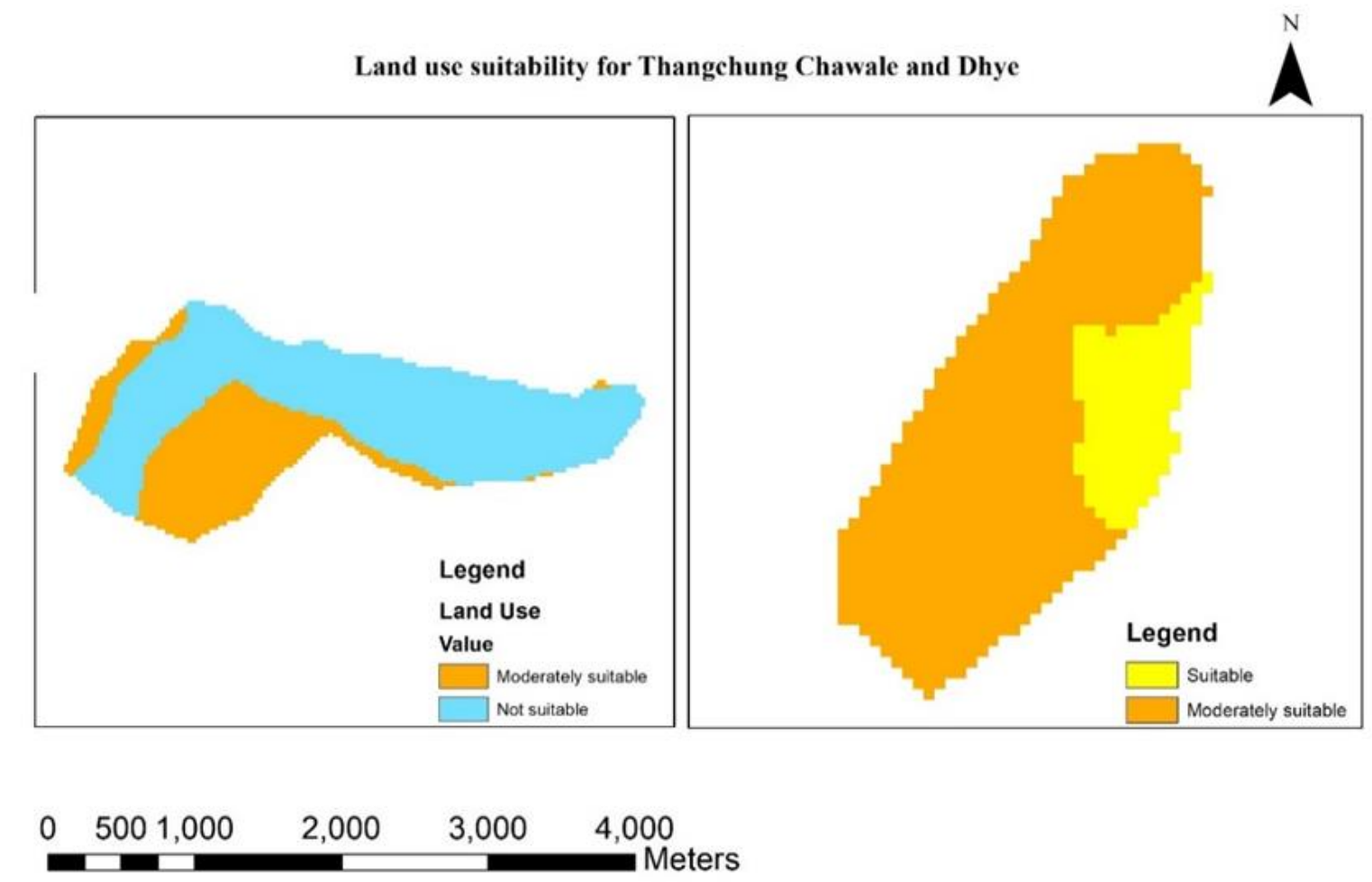

practices.

Figure 11: Land suitability maps for land use

The Figure 11 exhibits land use suitability for agriculture, which is classified into 3 classes as highly suitable, moderately suitable and not suitable. The result shows that at the resettlement area, i.e., Thangchung Chawale, 106.21 ha area is moderately suitable (barren land) and 225.81 ha area is unsuitable (sand, gravel and boulders). In the Dhye village, 15.84 ha area is suitable (agriculture valley) and 72.99 ha area is moderately suitable (shrub land/grassland and barren land).

The Figure 12 illustrates land suitability for slope, which was calculated according to the guideline of FAO into 7 slope classes in percent. In the resettlement area, 110.7 ha area of land is suitable that includes flat and gently sloping relief. Similarly, 168.21 ha and 38.7 ha area are moderately suitable (includes sloping and hilly relief) and unsuitable (includes mountainous to very steep mountainous relief), respectively. On the other hand, in Dhye, 14.31 ha is suitable, and 64.17 ha and 10.35 ha area are moderately suitable and unsuitable, respectively. 


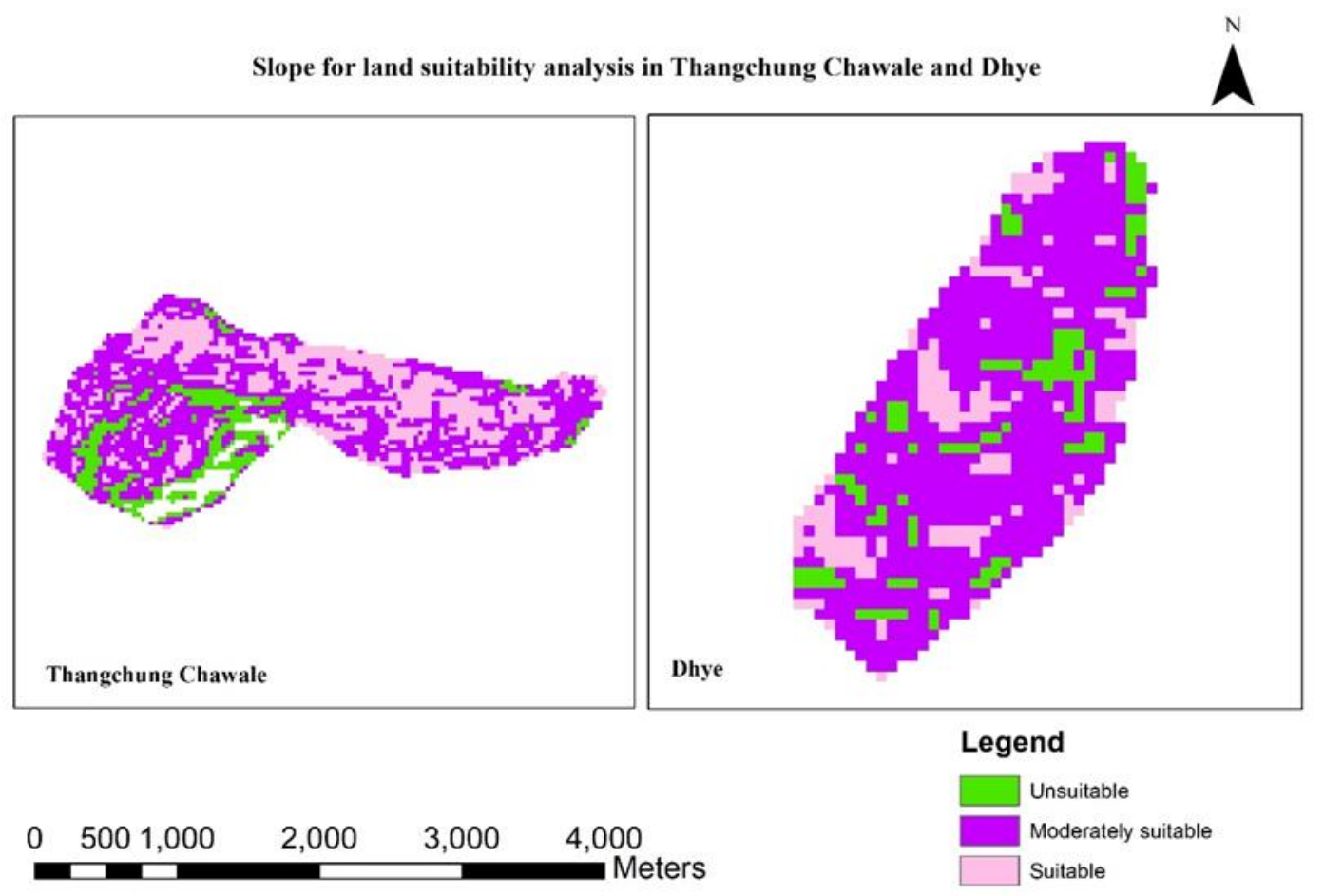

Figure 12: Land Suitability maps for Slope

Erosion Hazard for land suitability in Thangchung Chawale and Dhye
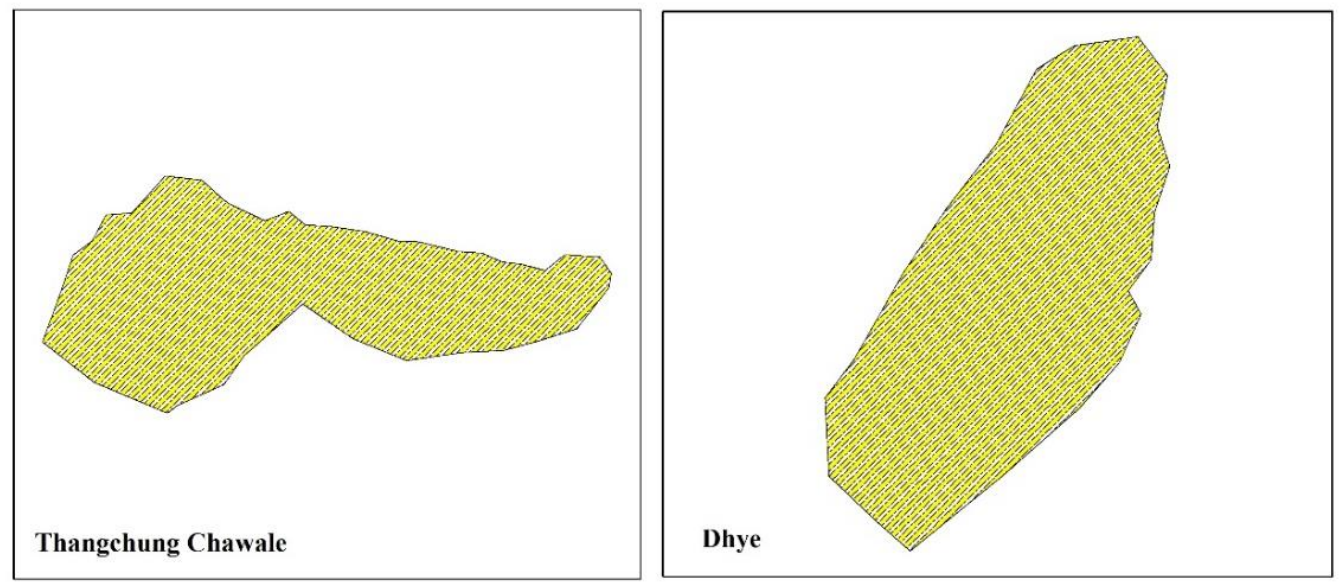

\section{Legend}

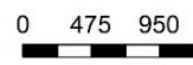
1,900 2,850 3,800

Erosion

Figure 13: Land Suitability maps for Erosion 
The Figure 13 exhibits that entire area of both the resettlement sites has soil erosion hazard, which is severe due to their geographical location and climate.

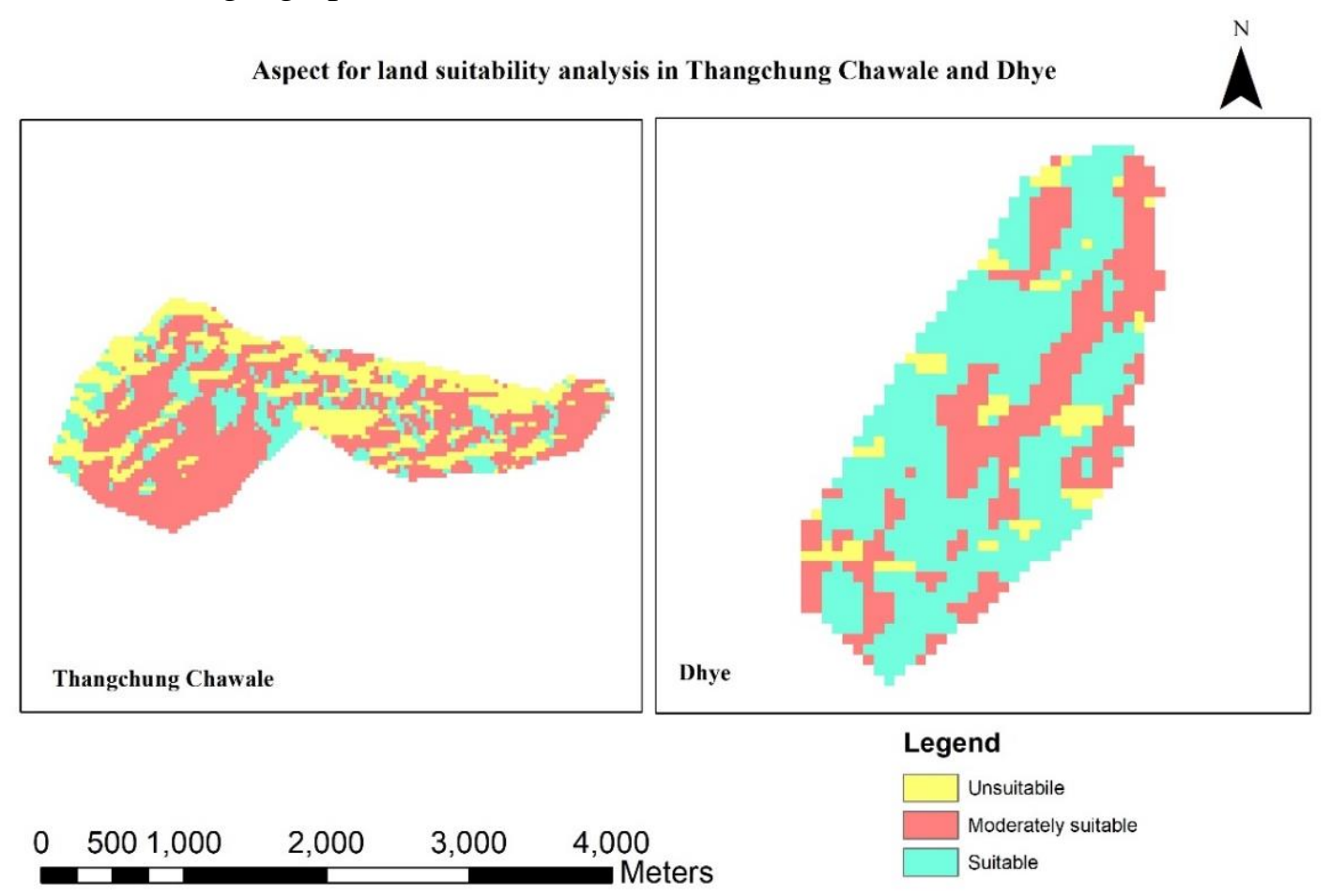

Figure 14: Land suitability maps for aspect

The Figure 14 exhibits that, in the Thangchung Chawale, 54.63 ha area is suitable, and 178.92 ha and 98.46 ha area are moderately suitable and unsuitable, respectively. Contrarily, only 52.47 ha area is suitable, and 29.7 ha and 6.66 ha area are moderately suitable and unsuitable, respectively, in Dhye.

The flood risk analysis is only done for the new settlement area as it lies at the confluence of the Kali Gandaki river, Dhye Khola and Tsarang Khola. The flood had occurred from Dhye Khola in the past. The Figure 15 shows that 165.51 ha area is suitable, and 166.5 ha area is unsuitable land in the Thangchung Chawale.

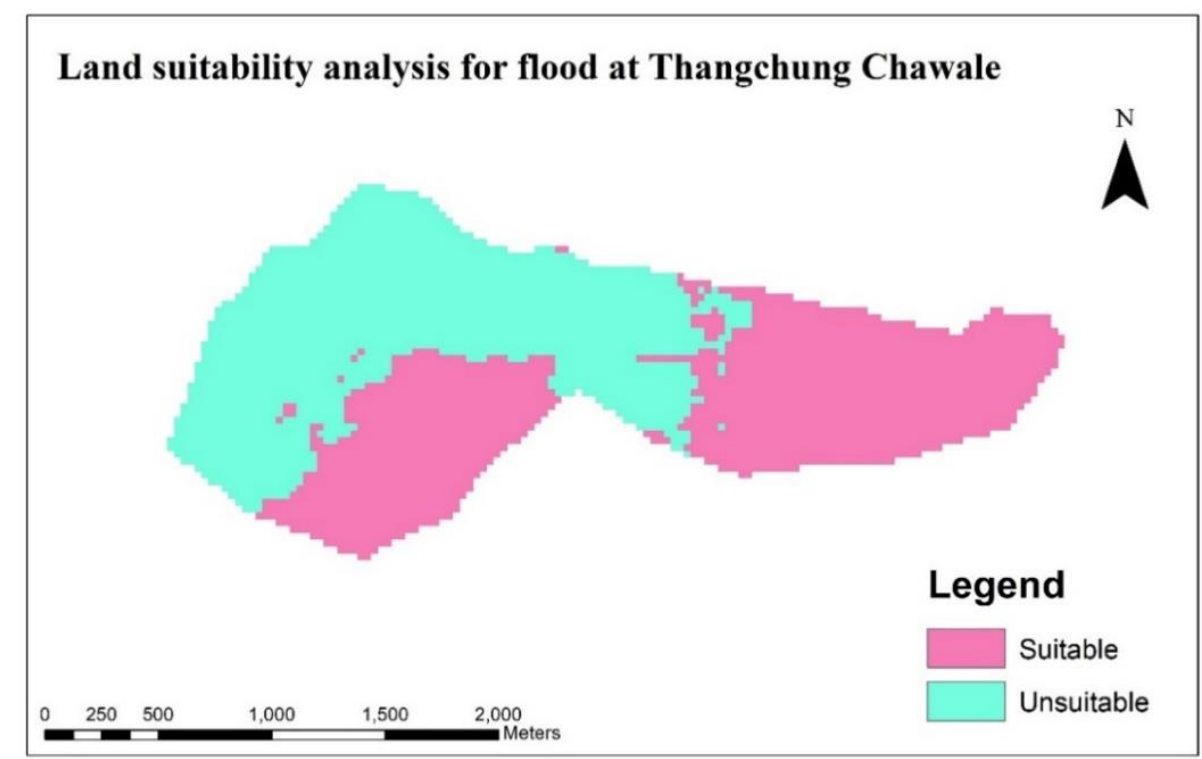

Figure 15: Land Suitability maps for Flood 


\section{Pairwise Comparison Between Two Sites for Land Suitability}

The Figure 16 shows the pairwise comparison done between all the sub-criteria of Thangchung Chawale and Dhye. All the scoring is given in percent, according to the weightage given to the criteria's importance. Finally, the maximum number is scored by Thangchung Chawale i.e. 0.7585, and Dhye has scored 0.3048 as shown in Table 6 below. The Thangchung Chawale is better than Dhye, as it has more area or land for cultivation. Water is available throughout the year. The slope suitability to construct buildings and cultivate land is more. The distance to the nearest health post is short and transportation access is available. Hence, these factors make the Thangchung Chawale suitable for resettlement.

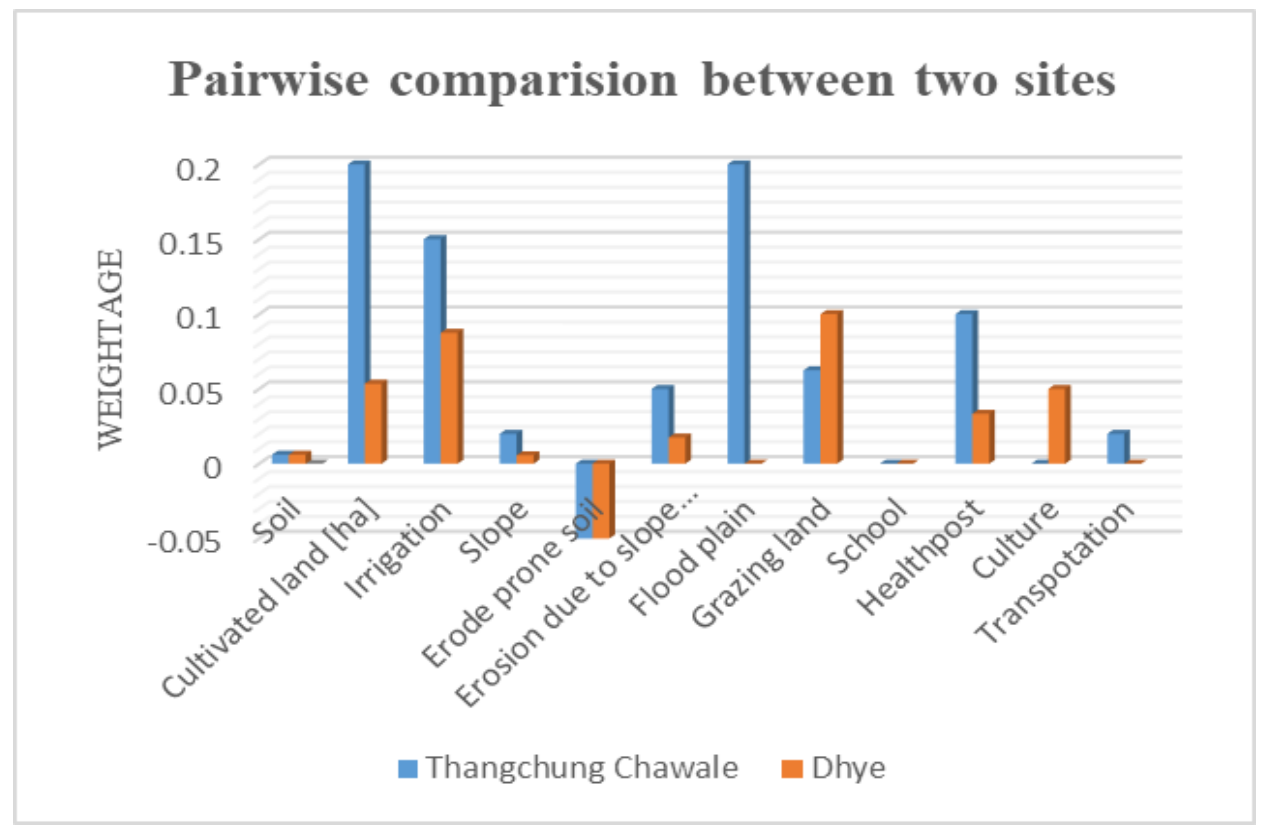

Figure 16: Pairwise comparison between two sites for land suitability

Summary of effect is shown in Table 6 highlighting the importance given in percentage for each criterion and weightage/score given between -1 to +1 to analyze the suitability for resettlement.

Table 6: Final land suitability analysis for resettlement

\begin{tabular}{|c|c|c|c|c|c|c|c|c|c|}
\hline Criteria & Subcriteria & $\begin{array}{l}\text { Thang- } \\
\text { chung } \\
\text { Chawale }\end{array}$ & Dhye & $\begin{array}{c}\text { Thang- } \\
\text { chung } \\
\text { Chawale }\end{array}$ & Dhye & $\begin{array}{l}\text { Weigh- } \\
\text { tage } 1\end{array}$ & $\begin{array}{l}\text { Weigh- } \\
\text { tage } 2\end{array}$ & $\begin{array}{c}\text { Thangchung } \\
\text { Chawale }\end{array}$ & Dhye \\
\hline \multirow[t]{4}{*}{ Agriculture } & Soil & Aridisol & Aridisol & 0.2 & 0.2 & \multirow[t]{4}{*}{$40 \%$} & $3 \%$ & 0.006 & 0.006 \\
\hline & $\begin{array}{l}\text { Cultivated } \\
\text { land [ha] }\end{array}$ & 332.19 & 88.83 & 1 & 0.26741 & & $20 \%$ & 0.2 & 0.05348 \\
\hline & Irrigation & 12 months & $\begin{array}{l}7 \\
\text { months }\end{array}$ & 1 & 0.58333 & & $15 \%$ & 0.15 & 0.0875 \\
\hline & Slope & 278.91 & 78.48 & 1 & 0.28138 & & $2 \%$ & 0.02 & 0.00563 \\
\hline \multirow[t]{2}{*}{ Erosion } & $\begin{array}{l}\text { Erode prone } \\
\text { soil }\end{array}$ & Yes/severe & $\begin{array}{l}\text { Yes/ } \\
\text { severe }\end{array}$ & -1 & -1 & \multirow[t]{2}{*}{$10 \%$} & $5 \%$ & -0.05 & -0.05 \\
\hline & $\begin{array}{l}\text { Erosion due to } \\
\text { slope aspect }\end{array}$ & 233.55 & 81.94 & 1 & 0.35085 & & $5 \%$ & 0.05 & 0.01754 \\
\hline
\end{tabular}


Doi: https://doi.org/10.33002/nr2581.6853.02121

\begin{tabular}{|c|c|c|c|c|c|c|c|c|c|}
\hline Criteria & Subcriteria & $\begin{array}{l}\text { Thang- } \\
\text { chung } \\
\text { Chawale }\end{array}$ & Dhye & $\begin{array}{c}\text { Thang- } \\
\text { chung } \\
\text { Chawale }\end{array}$ & Dhye & $\begin{array}{l}\text { Weigh- } \\
\text { tage } 1\end{array}$ & $\begin{array}{l}\text { Weigh- } \\
\text { tage } 2\end{array}$ & $\begin{array}{c}\text { Thangchung } \\
\text { Chawale }\end{array}$ & Dhye \\
\hline Flood & Flood plain & $\begin{array}{l}166.5 \text { ha } \\
\text { area is } \\
\text { prone to } \\
\text { flooding }\end{array}$ & $\begin{array}{l}\text { No } \\
\text { flood }\end{array}$ & 1 & 0 & $20 \%$ & $20 \%$ & 0.2 & 0 \\
\hline \multirow[t]{5}{*}{ Livelihood } & Grazing land & $8 \mathrm{hrs}$ & $5 \mathrm{hrs}$ & 0.625 & 1 & \multirow[t]{5}{*}{$30 \%$} & $10 \%$ & 0.0625 & 0.1 \\
\hline & School & & Closed & 0 & 0 & & $3 \%$ & 0 & 0 \\
\hline & Health post & $1 \mathrm{hr}$ & $3 \mathrm{hrs}$ & 1 & 0.33333 & & $10 \%$ & 0.1 & 0.03333 \\
\hline & Culture & Obstacle & Easy & 0 & 1 & & $5 \%$ & 0 & 0.05 \\
\hline & Transportation & yes & No & 1 & 0 & & $2 \%$ & 0.02 & 0 \\
\hline Total & & & & & & & $100 \%$ & 0.7585 & 0.30348 \\
\hline
\end{tabular}

\section{Discussion}

The migration in Mustang is not a new phenomenon. Viewing the history of the people of Mustang, they had migrated from Tibet to Mustang and the population of Upper Mustang used to speak Tibetan language as their mother tongue (Devkota, 2013). Their main job/occupation was rearing livestock such as yak, sheep/goat and horses. So, they usually led a nomadic life with cattle grazing on pasture lands. Now, the situation has changed. The people are living in community and cultivating the crops in addition to rearing livestock for survival. They had started cultivating green vegetables after the training given by Care Nepal about 30 years ago. The annual mean temperature of Jomsom has increased by $0.024^{\circ} \mathrm{C}$ during the period from 1986 to 2017 . People's perception on temperature matches the trend analyzed scientifically. This result is also similar to that inferred by NTNC (2012) and LAPA (2016). Similarly, the annual precipitation for all season is in increasing trend for Jomsom (1988-2017), while it is decreasing for Ghami (1983-2012). It is similar as reported in DHM (2017) and LAPA (2016) stating that higher the elevation, lower the precipitation trend.

When analyzing the reasons for multiple number of migrations of the people of Dhye, there seem to be only the push factors. As far as migration from Ghayu and Jhong is concerned, the reasons appear to be the harsh climatic conditions - cold weather, water and agricultural deficits, soil erosion, etc. At the same time, the pull factors such as enough water, agricultural land and grazing land attracted them to migrate to Dhye. They were living there happily for nearly 300-400 years. However, as per the crops production trend analysis, the annual production of crops is decreasing except that of apples. According to the household survey and key informant interview, they do not cultivate in $75 \%$ of the land from almost 40 years. Wild herb Jimbu is getting extinct and the climatic condition seems to be becoming conducive for apple farming in the higher altitude (Rana et al., 2011; RAD, 2015). This might be due to the changes in climatic pattern (NTNC, 2012). The rise in temperature has increased the apple production pattern in Upper Mustang (Regmi, Paudyal and Bordoni, 2009; Gurung, 2015). 


\section{Conclusion}

The people of Dhye have been migrating at different time intervals and places because of both push factors and pull factors. They migrated from Ghayu and Jhong due to push factor in search of new opportunities for their livelihood options. Then they found Dhye village with enough settlement space, water and grazing land. These factors pulled them to resettle in Dhye village 500-1000 years ago. There was no correlation between climate change and migration at that time. According to DHM (2017) and other researches and from household survey and key informants, it seems the temperature is increasing, and precipitation trend is changing (seasonal, duration, intensity and volume) leading to drought. The drying of water resources has degraded grazing lands and crop production has reduced drastically. As a result, people have migrated to nearby places, even to foreign countries, looking for better lives for themselves and for their families. Therefore, it is apparent that their third migration from Dhye to Thangchung Chawale was happened due to the adverse impact of climate change during the last 40 years. As they were forced to move from Dhye due to drought and water scarcity leading to low productivity, they have been tagged "climate refugee" and migration became their adaptation strategy to cope with climate change. The people of Dhye having experiences of three migrations, have not only faced hardships related to social and economic resources but have also faced difficulties in maintaining their cultural values, indigenous practices and ancestral heritages.

The land suitability analysis indicates that the Thangchung Chawale has scored high rank and has become more suitable for Dhye people in terms of cultivated land, water availability, distance to the nearest health-post and transportation. This result supports the decision of the Dhye people to relocate to that place.

\section{Recommendations}

- Now it's a high time to establish this community as a climate smart/resilient village community so that they do not need to migrate again and again.

- As Thangchung Chawale lies in flood plain, all the mitigation and prevention options must be adapted.

- Chawale lies on flood debris and other crops can't be cultivated. Cash/tree crops such as apple, walnut and other fruits and bhotepipal and bains can be planted to make the area less prone to flood events.

- Although the Dhye Khola water stream is available throughout the year, its quality is not good for drinking purpose. So, appropriate interventions for water treatment with advance technologies must be installed to purify the water.

- Awareness program about climate change and their mitigation and adaptation measures can be promoted to combat the adverse impact of climate change.

- The cultivation of apple and some other crops is happening new in this place, and result is very positive. So, the cultivation of new species can be promoted to enhance their socioeconomic conditions. 
Doi: https://doi.org/10.33002/nr2581.6853.02121

\section{Acknowledgement}

I would like to express my deepest sense of gratitude and heartfelt appreciations to supervisor, Mr. Ajay B. Mathema and co-supervisor, Mr. Manjeet Dhakal, both belonging to SchEMS College and Clean Energy Nepal.

\section{References}

Christensen, M. and Heilmann, C. J. (2009). Forest Biodiversity Gradients and the Human Imapct in Annapurna Conservation Area, Nepal. Biodivers Conserv, 18: 2205-2221.

Devkota, F. (2013). Climate Change and its Socio-cultural Impact in the Himalayan Region of Nepal. A Visual Documentation. Anthrovision. Vaneasa Online Journal, (1.2).

DHM (2017). Observed Climate Trend Analysis in the Districts and Physiographic Regions of Nepal (1971-2014). Kathmandu, Nepal: Department of Hydrology and Meteorology.

Dhungel, R. K. (2002). The Kingdom of Lo (Mustang): A Historical Study. Kathmandu: Tashi Gephel Foundation.

Gurung, G.S. (2015). Increasing Vulnerability of Mustang: A Personal Account. Meeteri, Vol.4. IPCC (2007). Climate Change 2007: The Physical Science Basis. Contribution of Working Group I to the Fourth Assessment Report of the Intergovernmental Panel on Climate Change. New York: University of Cambridge.

Jha, C. K., Gupta, V., Chattopadhyay, U. and Sreeraman, B. A. (2018). Migration as Adaptation Strategy to Cope with Climate Change: A study of farmers' migration in rural India. International Journal of Climate Change Strategies and Management, 10(1): 121-141. doi: doi:10.1108/IJCCSM-03-2017-0059.

LAPA (2016). Climate Change Local Adaptation Plan for Action: Conservation Area Management Committee, Surkhang Village Development Committee, Mustang. Government of Nepal.

NTNC (2012). Climate Change Impact on Livelihood and Natural Resources of Upper Mustang. Kathmandu, Nepal: Forestry Nepal. Available at: https://www.eldis.org/document/A63845.

RAD (2015). Statistical Information of Apple Farming. Ministry of Agricultural Development, Nepal Government, Kathmandu.

Rana, R.S., Bhagat, R., Kalia, V. and Lal, H. (2011). The Impact of Climate Change on a Shift of the Apple Belt in Himachal Pradesh: Handbook of Climate Change and India. Chapter 3, pp 12. Online : https://www.taylorfrancis.com/books/e/9780203153284/chapters/10.4324/97802031532 84-13.

Regmi, B.R., Paudyal, A. and Bordoni, P. (2009). Climate Change and Agro biodiversity in Nepal: Opportunities to Include Agrobiodiversity Maintenance to Support Nepal's National Adaptation Programme of Action (NAPA). Pokhara, Nepal: LI-BIRD.

Ruben, A., Garcia, G. and Frankentein, S. (2015). USCS and the USDA Soil Classification System: Development of a Mapping Scheme. Cold Regions Rsearch and Engineering Laboratory: ERDC/CRREL TR-15-4.

Scheffran, J., Marmer, E. and Snow, P. (2012). Migration as a Contribution to Resilience and Innovation in Climate Adaptation: Social Networks and Co-development in Noerthwest Africa. Applied Geography, 33: 119-127.

Sharma, E. and Tsering, K. (2009). Climate Change in the Himalayas: The Vulnerability of Biodiversity. Sustain Mt. Dev, 55: 10-12.

Shrestha, H.K. (2016). Preventing More Climate Refugees in Npal: Building Knowledge for Climate Resilience in Nepal. Nepal Academy of Science and Technology, pp.5 